Intet nyt fra bojrefronten

Henryk M. Broder (2008): Hurra vi kapitulerer! Om hysten til at overgive sig, Kobenhavn: Jyllands-Postens Forlag, 144 s., $169 \mathrm{kr}$.

I den tyske journalist og forfatter Henryk M. Broders bog Hurra vi kapitulerer! tages karikaturstriden, den efterhånden gamle sag om muhammedtegningerne, endnu engang under kærlig behandling. Henryk Broder er i Tyskland kendt for sin skarpe pen, som fra tid til anden får lov at sprutte i bl.a. Spiegel og Weltwoche, samt er forfatter til flere bøger om kontroversielle politiske emner. Kontroversiel forsøger han også at være i denne debatbog, der desværre skuffer på flere punkter.

I bogens første kapitel genfortæller Broder på baggrund af rapporten fra de to JP-journalister John Hansen og Kim Hundevadt forløbet under og efter tegningerne, en historie, der i dag er de fleste danske avislæsere velkendt. Det er yderst interessant at få et fremmed perspektiv på striden, og dét leverer Broder. Broders hensigt er at vise det absurde og groteske $i$ hele sagen, eller som han siger det $\mathrm{i}$ bogen: "Diskussionen om, bvilke blasfemiske provokationer vi skal undlade, for at de ikkee skal fole sig kranket, forer nodvendigvis ind $i$ det absurdes rige. Skal fromme joder forlange af ikke-joder, at de ikke spiser svinekod? Må en bindu gå amok, fordi schweizerne ikke anerkender koens bellighed og uantastelighed?" (s.30) Svaret er for Broder et rungende nej. Resten af bogen er én lang opremsning af muhammedsager i miniformat, der udstiller, hvad Broder ser som Europas og den vestlige verdens fallit over for muslimer, islam og islamisme. Og her skelner Broder ikke altid så nøje.

Så langt, så godt. Når Broder er god, lever han helt op til sine forbilleders skarphed, som han flere gange henviser til, bl.a. den franske forfatter og debattør Alain Finkelkraut og hollandske Ayaan Hirsi Ali. Om Finkelkraut, der i forbindelse med urolighederne i de parisiske forstæder i 2005 i et interview lagde vægt på ballademagernes etnicitet som muslimske sorte eller arabere, siger Broder, at han tør opføre sig "som barnet i H.C. Andersens Kejserens nye klader. Det, han sagde, var ikke så vigtigt, som den kendsgerning, at han forbrod sig mod det alment vedtagne". (s. 84) At turde det er ifølge Broder en journalistisk dyd og for så vidt også det, han selv praktiserer, nemlig at sige enhver politisk korrekthed midt imod. Broders ærinde i bogen er kort og godt et opgør med det han skiftevis betegner politisk korrekthed, eftergivenhedspolitik og venstreorienteret godhedsindustri.

Der, hvor kæden hopper af er, når Broder stirrer så indædt på sin modstander, at han ser sig fuldstændig blind på hans argumenter og tillægger ham motiver, der ikke er belæg for. Bogen igennem tordner Broder skiftevis mod Günter Grass, De Grønnes Claudia Roth, den venstreorienterede avis taz, og diverse vage avisredaktører, skoleledere og politikere, der ifølge Broder ikke tør statuere nogen 
eksempler, som kan vise alverdens muslimer, hvor skabet skal stå - og i tilfældet med karikaturstriden turde kæmpe for retten til at håne og fornærme samt at forsvare ytringsfriheden for enhver pris.

Det har den konsekvens, at bogen hurtigt bliver en ret monoton opremsning af eksempler, der alle har til hensigt at vise, at Broder har ret $i$ sin antagelse, den antagelse, der kort og godt går ud på, at Europa er ved at gentage en af den nyere histories mest fatale fejltagelser, nemlig appeasementpolitikken. Dengang, i 30'erne, var det som bekendt de allierede, der førte eftergivenhedspolitik over for Hitler, i dag er det hele Europa - bortset fra nogle få modige journalister og politikere - der undlader at sætte ind over for det, Broder ser som gentagne provokationer fra den muslimske verden, lige fra egentlige terrorhandlinger over Ahmadinejads provokerende udenrigspolitik til herboende muslimers krav om respekt og positiv særbehandling. Vesten foretager i disse år en total kapitulation over for islam eller slet og ret: begår kollektivt kulturelt selvmord. Hvad blev der af den stolte europæiske kultur?, spørger Broder gentagne gange.

Netop denne antagelse er interessant, men $i$ stedet for at forsøge at trænge dybere ind i appeasement-politikkens væsen dengang og nu for at forstå motiverne bag, dvs. for at forstå den angst eller for så vidt den pragmatik, der ligger til grund, affærdiger Broder den blot én gang for alle som fejhed. Man føler sig som læser snydt og sidder med en fornemmelse af, at Broder slipper lidt for nemt om ved at argumentere for sine hypoteser. Her er det nødvendigt som læser at stoppe op og få lidt af den redelighed på banen, som forfatteren ellers plæderer for. Når det drejer sig om konkrete eksempler på det, man kunne kalde 'undladelseshandlinger' eller selvcensur, som vi også har oplevet herhjemme i kølvandet på karikaturstriden, så kan man vel egentlig ikke fortænke tegnere, kunstnere, journalister, forfattere og avisredaktører $i$ at pålægge sig selvcensur, efter de trusler og attentatplaner, som Flemming Rose og Kurt Westergaard er blevet udsat for. Man kan ikke, som Broder gør det, stemple en personlig beslutning om tilbageholdenhed, som fejhed. Der er langt flere følelser og overvejelser i spil.

Broders grundholdning er den, at Europa har udviklet sig til lidt af en kaffeklub med evindelige diskussioner og debatter om, hvorvidt vi gør det rigtige og hvordan vi bevarer verdensfreden. Vi skulle hellere handle og statuere nogle eksempler og stoppe den evindelige snakken. Der er et vist slægtskab mellem Broder og amerikanske neocons, hvis no mercy-holdning, han deler. Han er fuldstændig enig i, at Europa, som det har udviklet sig, på ingen måde selv er i stand til at tackle den islamis(tis)ke trussel, men har brug for storebror USA til at gøre det beskidte arbejde, når det virkelig brænder på. Til denne holdning er 
der at sige, at den let bliver en lige så hård og ubønhørlig strategi som den de militante islamister benytter sig af - og hvad blev der så af det demokrati, som Broder jo netop forsvarer som europæisk adelsmærke?

Følger vi Broders strategi til ende om at sætte hårdt mod hårdt, vil vi ganske givet opleve, at han får ret i sin profeti, nemlig at vi med muhammedkrisen kun har set toppen af isbjerget, hvad angår konflikter med den islamiske verden. Er det det vi vil? Det er det spørgsmål, man bør stille sig selv og med rette kan stille Broder. Deeskalation er i hvert fald ikke noget der står højt på hans liste.

Et sted i bogen henviser Broder til den tidligere tyske kansler og SPDpolitiker Helmut Schmidt og citerer hans svar på, hvordan vi i den vestlige verden skal forholde os til Iran og præsident Ahmadinejads påfund: " $V i$ burde vare mere talmodige, og iscr USA burde bolde sig mere tilbage" (s.77). Dette udsagn er måske i virkeligheden ikke så tosset, som Broder gerne vil gøre det til, nemlig som et ærkeeksempel på appeasement. Måske ligger der en del fornuft $i$ at tage den med ro og ganske enkelt holde sig tilbage, når islamistiske grupper og ledere fremturer. Broders strategi med at sætte hårdt mod hårdt har i hvert fald én helt åbenlys konsekvens, nemlig den at de islamistiske grupper får masser af bevågenhed og opmærksomhed, den PR, der i høj grad er deres eksistensgrundlag. En appeasement-holdning, som $\mathrm{fx}$ den Helmut Schmidt udtrykker, er i øje- blikket vort bedste våben mod fanatiske gruppers fanatiske fremturen. Og så satiren og humoren. Den må vi ikke glemme. Her er vi så tilbage ved karikaturstriden, som vi stadig heftigt diskuterer.

Rikeke Lonise Peters

\section{Middelalderen rehabiliteret}

\section{Steffen Heiberg: En ny begyndelse}

- Europas Kulturbistorie $i$ middelalderen. Gads forlag. 528 sider, 399 kr.

Der hersker et utal af om myter vedrørende middelalderen. Man kan sige, middelalderen har ikke haft det let. Siden renæssancen - der var storproducent af nedgørende myter og bestemmelser angående den umiddelbart forudgående tid (den mørke tid, som det hed), op igennem oplysningstiden, med et kort afbræk i romantikken, hvor fænomenet middelalder blev romantiseret og myternes antal samt forvredne indhold ikke blev mindre, frem igennem 1800tallet, da renæssancesværmeriet tog til i en indtil da uset grad hen imod slutningen af århundredet og hermed også nedgøringen af den forudgående mørke tid frem til nazismens ideologi, der med Reichsführer-SS Heinrich Himmler i spidsen til gengæld i egen optik og ønsketænkning dyrkede middelalderen som den rene guldalder, for så selvfølgelig efter nazismens fald atter at blive betragtet negativt, ofte i forlængelse af just nazismens groteske phantasmer - har middelalderen været Prügelknabe i den vestlige offentlighed. Holdningen 